\title{
Insights Into the Role of Vitamin D as a Biomarker in Stem Cell Transplantation
}

\author{
Jose Ros Soto ${ }^{1 *}$, Chloe Anthias ${ }^{1,2}$, Alejandro Madrigal ${ }^{1}$ and John A. Snowden ${ }^{3}$ \\ ${ }^{1}$ Anthony Nolan Research Institute, Royal Free Hospital and University College London, London, United Kingdom, \\ ${ }^{2}$ Department of Haemato-Oncology, The Royal Marsden Hospital, Sutton, United Kingdom, ${ }^{3}$ Department of Haematology, \\ Sheffield Teaching Hospitals NHS Foundation Trust, Sheffield, United Kingdom
}

\section{OPEN ACCESS}

Edited by:

Jukka Partanen,

Finnish Red Cross Blood

Service, Finland

Reviewed by:

Anne Mary Dickinson, Newcastle University, United Kingdom

Constanca Figueiredo,

Hannover Medical School, Germany

*Correspondence:

Jose Ros Soto

jose.soto.16@ucl.ac.uk

Specialty section:

This article was submitted to Alloimmunity and Transplantation,

a section of the journal

Frontiers in Immunology

Received: 27 September 2019 Accepted: 24 April 2020

Published: 08 June 2020

Citation:

Soto JR, Anthias C, Madrigal A and Snowden JA (2020) Insights Into the Role of Vitamin D as a Biomarker in Stem Cell Transplantation.

Front. Immunol. 11:966.

doi: 10.3389/fimmu.2020.00966
Vitamin D was discovered 100 years ago and since then multiple studies have consistently proved its effect on bone health and mineral metabolism. Further research has also explored its so-called "non-classical" biological effects, encompassing immune regulation and control of cell proliferation and differentiation. Vitamin D downregulates pro-inflammatory immune cells and subsequently their cytokine production, while enhancing the anti-inflammatory subsets, thus mediating inflammation and fostering a more tolerogenic environment. Its biological action is exerted through the vitamin $D$ receptor, a nuclear receptor that mediates gene transcription and is expressed in most cells from the innate and adaptive immunity. Owing to its immune-modulatory properties, its role in cancer pathophysiology, hematology disorders and stem cell transplantation has also been investigated. Vitamin D deficiency causes immune imbalance and cytokine dysregulation, contributing to some autoimmune diseases. In the hematopoietic stem cell transplant setting this could lead to complications such as acute and chronic graft-versus-host disease, ultimately impacting transplant outcomes. Other factors have also been linked to this, including specific polymorphisms of the vitamin $D$ receptor in both stem cell donors and recipients. Nevertheless, studies thus far have shown conflicting results and the use of vitamin $D$ or its receptor as biomarkers has not been validated yet, therefore there are no evidence-based consensus guidelines to guide clinicians in their day-to-day practice. To gain more insight in this topic, we have reviewed the existent literature and gathered the current evidence. This is an overview of the role of serum vitamin $D$ and its receptor as biomarkers for clinical outcomes in patients undergoing hematopoietic stem cell transplantation. Further prospective studies with larger cohorts are warranted to validate the viability of using serum vitamin D, and its receptor, as biomarkers in potential stem cell donors and patients, to identify those at risk of post-transplant complications and enable early therapeutic interventions.

Keywords: supportive care, Vitamin D, hematopoietic stem cell transplantation, 25(OH)D3, post-transplant complications, graft-versus-host disease

\section{INTRODUCTION}

Vitamin D has received considerable attention in recent years due to its non-skeletal functions $(1,2)$, particularly immune regulation (3). Vitamin D receptor-mediated signaling promotes innate immunity and modulates adaptive immune responses (4-8). This has reinvigorated the interest in vitamin D in the field of hematopoietic stem cell transplant (HSCT) (9-14), where recipients are 
at high risk of vitamin D deficiency (15-20). Since this can lead to complications post-HSCT, including graft-versus-host disease (GvHD), identifying patients at risk of vitamin D deficiency is crucial to enable prompt therapeutic interventions and reduce transplant-related morbidity and mortality $(9,19)$.

At the beginning of the twentieth century, rickets had become a major public health issue due to its high incidence in the UK population. At the University of Sheffield, Professor Sir Edward Mellanby performed extensive research on dogs with rickets that led to the discovery of vitamin D in 1919. It was called the "antirachitic accessory factor," "antirachitic vitamin," or "fatsoluble vitamin" (as it was contained in butter and animal fat) $(21,22)$. In cooperation with his wife, May Mellanby, they studied puppies and found that the cod-liver oil had a fundamental role in bone calcification (23).

Professor Mellanby extrapolated his research to humans, where lower-social-class children with a diet rich in milk (included those who were breastfed), eggs, or fish had a lower incidence of rickets, better jaws and teeth compared to those from the high class, whose diets were lacking in these aliments (21).

\section{Vitamin D Metabolism}

Vitamin D is a fat-soluble secosteroid (steroid with a "broken" ring) $(8,24)$ mainly synthesized in the skin $(70-80 \%)(25)$. The remaining $20-30 \%$ is consumed with diet: Mushrooms, egg yolk, and oily fish (mackerel, sardines, herrings and salmon) contain high concentrations of vitamin D (8). For decades, cod liver oil has been regularly used for both the prevention and treatment of infectious diseases, such as tuberculosis $(26,27)$. When taken with the diet, both vitamin $\mathrm{D}^{2}$ and vitamin $\mathrm{D}^{3}$ are absorbed in the small bowels similarly to lipids and then transported to the liver through the lymphatic vessels (28).

When the solar ultraviolet light B radiation (spectrum 280320 UVB) hits the epidermis, the 7-dehydrocholesterol (also called pro-vitamin $D$ ) is transformed into pre-vitamin $D^{3}(29)$. Immediately after, a thermal reaction produces the isomerization of this into vitamin $\mathrm{D}^{3}$, or cholecalciferol, the inactive form of vitamin $\mathrm{D}$. The higher the UVB intensity, the higher the quantity of vitamin $\mathrm{D}^{3}$ is synthesized. This process takes up to 3 days after the skin has been exposed to sunlight. Consecutively, the vitamin $\mathrm{D}^{3}$-binding protein (DBP; an alpha-1 globulin plasma carrier) bounds to vitamin $\mathrm{D}^{3}$ and releases it into the bloodstream (30).

The first hydroxylation is held in the liver, and the main enzyme is 25-hydroxylase (CYP2R1) (6). The quantity of $25(\mathrm{OH}) \mathrm{D}^{3}$ or calcidiol hydroxylated is proportionate to the total amount of vitamin $\mathrm{D}$ both synthesized and ingested with the diet, thus making this the most reliable marker of vitamin D serostatus (31). This is still inactive but has a longer lifespan (between 2 and 3 weeks) than its active counterpart (32). The second hydroxylation takes place primarily in the kidney by $1 \alpha$-hydroxylase (CYP27B1) (6). Calcitriol or $1,25(\mathrm{OH})_{2} \mathrm{D}^{3}$ is the biologically active hormone (24). CYP27B1 is also found in other organs, including skin, lymph nodes, colon, central nervous system, adrenal glands, pancreas, placenta, sweat glands and the immune cells $(6,7,33,34)$. Finally, 24hydroxylase (CYP24A1) catabolizes $1,25(\mathrm{OH})_{2} \mathrm{D}^{3}$ into calcitroic acid, functionally inactive. This is excreted through the bile and subsequently the faeces, as well as the urine, avoiding toxic levels (35). This reaction occurs in cells that possess the vitamin D receptor $(\mathrm{VDR})(1,6,24)$. Interestingly, CYP24A1 is upregulated in tumor cells to abrogate the vitamin D-related anti-tumor effects (36).

\section{Vitamin D Receptor (VDR)}

Vitamin D acts as a ligand-inducible transcription factor binding to the VDR, a member of the nuclear hormone receptors superfamily. It is located in most of the cells in humans, including those within the immune system (7).

Vitamin D, as a lipophilic molecule, passes through the cellular membrane and binds the VDR in the nucleus. The vitamin D-VDR complex forms a heterodimer with the Retinoid X Receptor (RXR), which is subsequently bound to the VitaminD-Responsive Elements (specific sequences of DNA in the promoter region of the vitamin $\mathrm{D}$ responsive genes), controlling the transcription of these genes $(32,37)$. On the one hand, some genes can be upregulated by $1,25(\mathrm{OH})_{2} \mathrm{D}^{3}$ itself, including those encoding CYP24A1, leading to an increase catabolism of $1,25(\mathrm{OH})_{2} \mathrm{D}^{3}$, or CAMP, that enhances the production of cathelicidin, an antibacterial peptide. On the other hand, it downregulates genes, such as those of IL- 2 and IFN- $\gamma$ (interferon gamma) in T cells (7). Interestingly, VDR in osteoblast mediates between the nervous system and the bone marrow niche, promoting stem cells mobilization after G-CSF (granulocyte colony stimulating factor) administration (38).

\section{Vitamin D Function}

The biological functions of vitamin $\mathrm{D}$ are divided into classical $(32,39,40)$ and non-classical $(1,6,24)$, as displayed in Figure 1.

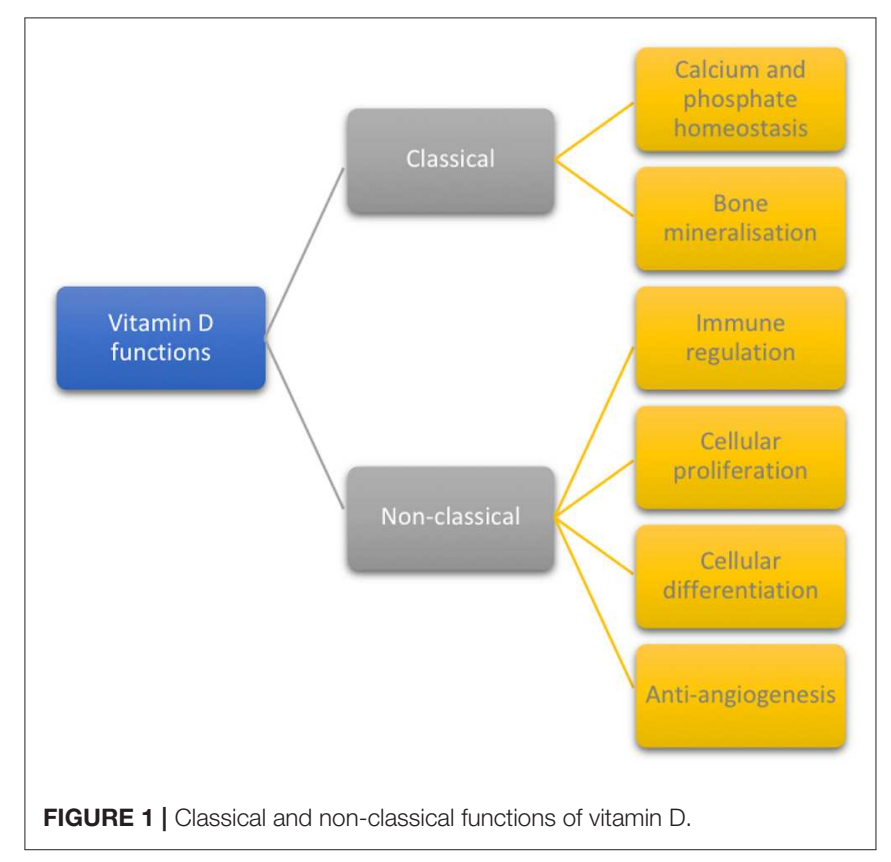




\section{EFFECT OF VITAMIN D IN THE IMMUNE SYSTEM}

VDR is found in cells from innate $(3,41-46)$ and adaptive (3, 42, 47-50) immunity. Vitamin D exerts its immuneregulatory function, inhibiting the pro-inflammatory cells with a subsequently downregulation of their hallmark cytokines while enhancing the anti-inflammatory subsets, maintaining the immune tolerance (4-8). As an example, pro-inflammatory cytokines, such as TNF- $\alpha$ (tumor necrosis factor alpha), IL-1 and IL-6 decrease during summer months, when vitamin $\mathrm{D}$ reaches its peak level in blood $(4,6,8)$.

Immune cells can transform $25(\mathrm{OH}) \mathrm{D}^{3}$ into its active form because they express the enzyme CYP27B1 $(8,42,51,52)$. In addition, they control the local metabolism of vitamin $\mathrm{D}$ selfconsuming the manufactured vitamin or secreting to the adjacent cells $(8,33)$. However, for optimal modulation of immune responses, this system relies on the availability of systemic $25(\mathrm{OH}) \mathrm{D}^{3}$, as $1,25(\mathrm{OH})_{2} \mathrm{D}^{3}$ has a very short half life (8).

\section{Innate Immunity}

Vitamin D targets antigen-presenting cells as follows:

In neutrophils, vitamin $\mathrm{D}$ contributes to tissue preservation hampering IL-1b, a pro-inflammatory cytokine synthesized by neutrophils (53). In addition, an in vivo study showed that $1,25(\mathrm{OH})_{2} \mathrm{D}^{3}$ acts as a differentiation agent in leukemic retinoic acid-resistant promyelocytes into mature granulocytes (54).

Moreover, a link between $1,25(\mathrm{OH})_{2} \mathrm{D}^{3}$ and early neutrophil recovery post-HSCT suggest the potential role of this vitamin in immune reconstitution (10).

The production of $1,25(\mathrm{OH})_{2} \mathrm{D}^{3}$ increases throughout the maturation of dendritic cells (DCs) due to a higher expression of CYP27B1 (8). However, $1,25(\mathrm{OH})_{2} \mathrm{D}^{3}$ keeps DCs in an immature state to preserve immune tolerance $(43,55,56)$. From the DCs perspective, $1,25(\mathrm{OH})_{2} \mathrm{D}^{3}$ hampers interaction and priming of $\mathrm{T}$ cells inhibiting expression of receptors CD40, CD80, and CD86 in the DCs' surface $(55,56)$, diminishing the secretion of IL12 and concurrently of IFN- $\gamma(19,33,55-57)$, and suppressing DCs' migration to lymph nodes due to reduction of CCL21 and its receptor CCR7, blunting antigen presentation to T-cells $(43,44)$. It mainly impacts on the myeloid DCs, which interact and activate naïve T cells (57).

Vitamin D fosters macrophage maturation and enhances phagocytosis $(3,51)$. During infections, CYP27B1 is upregulated by viruses, cytokines, such as IFN- $\gamma$ or lipoproteins from the Mycobacterium membrane, resulting in an increase of $1,25(\mathrm{OH})_{2} \mathrm{D}^{3}$ synthesis. In addition, vitamin $\mathrm{D}$ regulates the expression of specific endogenous antimicrobial peptides, such as cathelicidin $(8,26,51,58)$, which has also been found to possess tumoricidal activity against high-grade lymphoma cells, contributing to rituximab-mediated cytotoxicity (59). Furthermore, vitamin D downregulates the expression of $\mathrm{MHC}$ (major histocompatibility complex) class II on the macrophage surface, hindering T-cell activation (41) and decreasing the pool of circulating $\mathrm{CD}^{+} 6^{+}$monocytes and their secretion of TNF- $\alpha(60)$.
Natural killer cells (NK) proliferation and cytotoxic function is abrogated by $1,25(\mathrm{OH})_{2} \mathrm{D}^{3}$, inhibiting the secretion of TNF- $\alpha$ and IFN- $\gamma(46,61)$. In the innate NK cells, it also upregulates the secretion of IL-4 (62).

\section{Adaptive Immunity}

VDR is also upregulated in activated B lymphocytes (63), inhibiting the synthesis of immunoglobulins $(6,47)$ and decreasing $\mathrm{B}$ cell proliferation and differentiation into plasma cells (64). Moreover the expression of CYP24A1 enables B cells to degrade $1,25(\mathrm{OH})_{2} \mathrm{D}^{3}$ into calcitroic acid and subsequently to eliminate it (42).

Vitamin D blunts inflammation and alloreactivity because it reduces the pool of activated $\mathrm{T}$ lymphocytes (50) and the production of TNF- $\alpha$, as shown in a study carried out in HSCT patients (64). VDR is upregulated in the activated T cells as well as in the naïve and early memory subsets, acting as a subrogate marker of T-cell activation (50, 65). To ensure sufficient supply of $1,25(\mathrm{OH})_{2} \mathrm{D}^{3}$ is provided to the neighboring cells $(8,62)$, CYP27B1 is upregulated, as well as $24 \alpha$-hydroxylase to avoid an overproduction of this vitamin (52).

In $\mathrm{CD}^{+}$, on the one hand, $1,25(\mathrm{OH})_{2} \mathrm{D}^{3}$ downregulates the production of IL-2 and IFN- $\gamma$ by Th1 $(52,64-66)$ and impairs IL-17 secretion by Th17 $(62,67)$. On the other hand, it helps expanding the pool of Th2 cells, with a subsequent upregulation of their landmark cytokines. One of them, IL-4, also triggers $24 \alpha-$ hydroxylase to prevent supra-physiological levels $(51,67)$. Part of the immune-modulatory effect of $1,25(\mathrm{OH})_{2} \mathrm{D}^{3}$ is due to the enhancement of the IL- 6 secretion, which abrogates the Th1 cells, skewed in favor of the anti-inflammatory and pro-tolerogenic Th2 subset (55).

Some studies have found contradictory results on the effect of vitamin $\mathrm{D}$ in $\mathrm{CD}^{+} \mathrm{T}$-cell proliferation, thus currently, no conclusions can be drawn $(49,64,68)$.

Despite controversy in this matter $(52,68)$, preclinical studies have shown that $1,25(\mathrm{OH})_{2} \mathrm{D}^{3}$ triggers secretion of IL-10 by $\mathrm{CD}^{+}{ }^{+} \mathrm{T}$ cells $(69)$ and TGF- $\beta$ (transforming growth factor beta) by $\mathrm{DCs}(55,57,67,70)$, which ultimately enhance the recruitment of Foxp $3^{+} \mathrm{CD}_{25}{ }^{+}$regulatory T cells (Treg) $(59,66)$. These CD4 ${ }^{+}$ lymphocyte subset impairs the expansion of alloreactive donor $\mathrm{T}$ cells in GvHD-target tissues and subsequently the synthesis of their pro-inflammatory cytokines, including IL-2 (71). Alongside this, $1,25(\mathrm{OH})_{2} \mathrm{D}^{3}$ downregulates the expression of skin and guthoming molecules (cutaneous lymphocyte-associated antigen and chemokine receptor CCR9, respectively) in the T cell surface, with a subsequent impairment in T cell trafficking $(52,68)$. This contributes to abrogate GvHD and foster a more tolerogenic immune environment $(62,70,72)$.

Moreover, a preclinical study postulated that a population of IL-10-secretor B cells could act as regulatory immune cells, but data is limited so further research is needed (52).

\section{VITAMIN D DEFICIENCY}

Currently, vitamin D deficiency is considered a pandemic disease (73). Although its prevalence in higher latitudes is well known, it can also affect individuals living in areas closer to the Ecuador 
(74). It can also affect individuals living in areas closer to the Ecuador $(25,74-76)$.

Many factors have been identified to contribute to it: age (77), low sunlight exposure (25), skin pigmentation, obesity and decrease of cutaneous synthesis of vitamin D. HSCT recipients can also suffer from malnourishment (31), malabsorption, or gut GvHD (35), which can have a detrimental impact on absorption of vitamin D-enriched aliments. In addition, vitamin D metabolism can be altered by immunosuppression $(35,78-$ 80 ) or as a consequence of kidney (35) or liver (79) impairment. Moreover, some genetic polymorphisms in genes related to the vitamin $\mathrm{D}$ metabolism have been identified in individuals at risk of vitamin D insufficiency (81).

The half life of the inactive metabolite $25(\mathrm{OH}) \mathrm{D}^{3}$ has been estimated to be between 2 and 3 weeks. It identifies individual adequacy or insufficiency, making it the most useful marker of the vitamin D body stores (32).

For over a century, most of the research performed regarding the vitamin $\mathrm{D}$ has been looking into its effect on bone health (23). Thus it is not surprising that the cut-off established for vitamin $\mathrm{D}$ deficiency has been based on the optimal serum levels of $25(\mathrm{OH}) \mathrm{D}^{3}$ required to prevent bone loose while maintaining calcium homeostasis (79). Nevertheless, little is known about the levels needed to enhance immune-regulation and forestall complications following $\operatorname{HSCT}(4,6,8)$, and so a threshold that can be applied into the HSCT setting has not been validated yet (9, 82-84).

In the general population, studies regarding this have shown remarkable discrepancies: whereas the Institute of Medicine advocates for a cut-off of $30 \mathrm{nmol} / \mathrm{L}(12 \mathrm{ng} / \mathrm{mL})$ (24), NICE guidelines and the Endocrine Society Task Force on Vitamin D established it below $25 \mathrm{nmol} / \mathrm{L}(10 \mathrm{ng} / \mathrm{mL})(78,85)$, and even one report has set it below $50 \mathrm{nmol} / \mathrm{L}(20 \mathrm{ng} / \mathrm{mL})(86)$. Therefore, it is not possible to suggest a cut-off that defines vitamin $\mathrm{D}$ deficiency in recipients of HSCT based on the evidence published so far.

Moreover, the non-skeletal functions of vitamin $\mathrm{D}$ have reinvigorated its interest as potential modulator in a broad spectrum of diseases and therapeutical procedures, as follows:

\section{Autoimmune Diseases}

Despite some clinical studies focused on the role of vitamin D deficiency have revealed its contribution to the pathophysiology of some autoimmune diseases, including multiple sclerosis, systemic sclerosis, rheumatoid arthritis, insulin-dependent diabetes and systemic lupus erythematous (4, 7, 45, 87), others could not reproduce these results $(88,89)$.

\section{Asthma}

Interestingly, studies performed in patients with asthma showed that patients with lower serum levels of vitamin D were less responsive to steroids than those with higher levels. The reason for this is the impaired steroid induction of IL-10 secretion by $\mathrm{CD}^{+} \mathrm{T}$ cells, leading to a poor recruitment of Tregs. However, it can be restored with vitamin D supplementation: Due to its immunomodulatory properties, vitamin $\mathrm{D}$ enhances the secretion of IL- 10 by $\mathrm{CD}^{+} \mathrm{T}$ cells, increasing the pool of both population of circulating Tregs (Foxp $3^{+}$and IL-10 Tregs) in vitro and contributing to the control of the disease, as seen in clinical studies $(66,70,72,90)$.

\section{Infectious Diseases}

Vitamin D has been used as a biomarker for critically ill patients with sepsis, whom levels of $25(\mathrm{OH}) \mathrm{D}^{3}$ were lower than those from patients also admitted in Intensive Care Unit but without sepsis (58). However, despite the evidence found in a few preclinical studies about the effect of $1,25(\mathrm{OH})_{2} \mathrm{D}^{3}$ fostering macrophage activity against Mycobacterium tuberculosis (49) or downregulating cytokine production during viral infections (91), data regarding infections is still controversial, including studies in HSCT patients $(11,49,92,93)$. Similarly, in a clinical study where vitamin $\mathrm{D}$ supplementation was given as adjunctive therapy to vaccinations, it did not show any clinical relevance (91).

\section{Cancer}

In vitro studies have shown that $1,25(\mathrm{OH})_{2} \mathrm{D}^{3}$ inhibits cellular proliferation (downregulating BCL-2 expression and telomerase activity) and angiogenesis (inhibiting VEGF, vascular endothelial growth factor), and acts as a pro-apoptotic and differentiationinducing agent in a range of malignant cells $(1,6,36,54,94-$ 96) because these cells possess VDR (97). In clinical studies, vitamin $\mathrm{D}$ serostatus has been linked to solid tumors, including melanoma (98-100), breast $(6,101,102)$, colon (6), prostate (102), and lung cancer (103). Furthermore, this anti-tumor effect has also been investigated in hematology disorders, such as myelodysplastic syndrome (96), myeloid leukemias $(95,96)$, and multiple myeloma (104). In some reports, higher levels of $1,25(\mathrm{OH})_{2} \mathrm{D}^{3}$ have been found to impact favorably in survival $(97,99,103,105)$. However, there has been some discrepancy in lymphoid malignancies, as a few studies found a positive impact of $1,25(\mathrm{OH})_{2} \mathrm{D}^{3}$ in outcomes $(95,97,106)$ whereas others did not $(107,108)$. Moreover, Hansson et al. showed that patients with malignant hematological disorders and vitamin D deficiency before transplantation could have higher relapse rate compared to those patients whom levels were higher (10). Supporting this, another paper mentioned similar results in patients with myeloid malignancies (109), whereas another failed to reproduce the same results (64).

\section{Solid Organ Transplantation}

Vitamin D deficiency is highly prevalent in heart and liver transplant recipients, predominantly in the latter because endstage liver failure alters vitamin $\mathrm{D}^{3}$ first hydroxylation (110). Furthermore, nearly $50 \%$ of lung transplant recipients are vitamin $\mathrm{D}$ deficient, as reported by one single center study. In this population, low levels of $25(\mathrm{OH}) \mathrm{D}^{3}$ were linked to worse pulmonary function tests and higher graft rejection (111). Moreover, recent reviews have reported how chronic kidney disease and kidney transplant can aggravate hypovitaminosis D and how patients with lower $25(\mathrm{OH}) \mathrm{D}^{3}$ serum levels were more likely to suffer from secondary tumors and graft rejection, leading to a poorer survival after transplantation $(104,112)$. In this context, vitamin D supplementation can play a reno-protective role (113). 


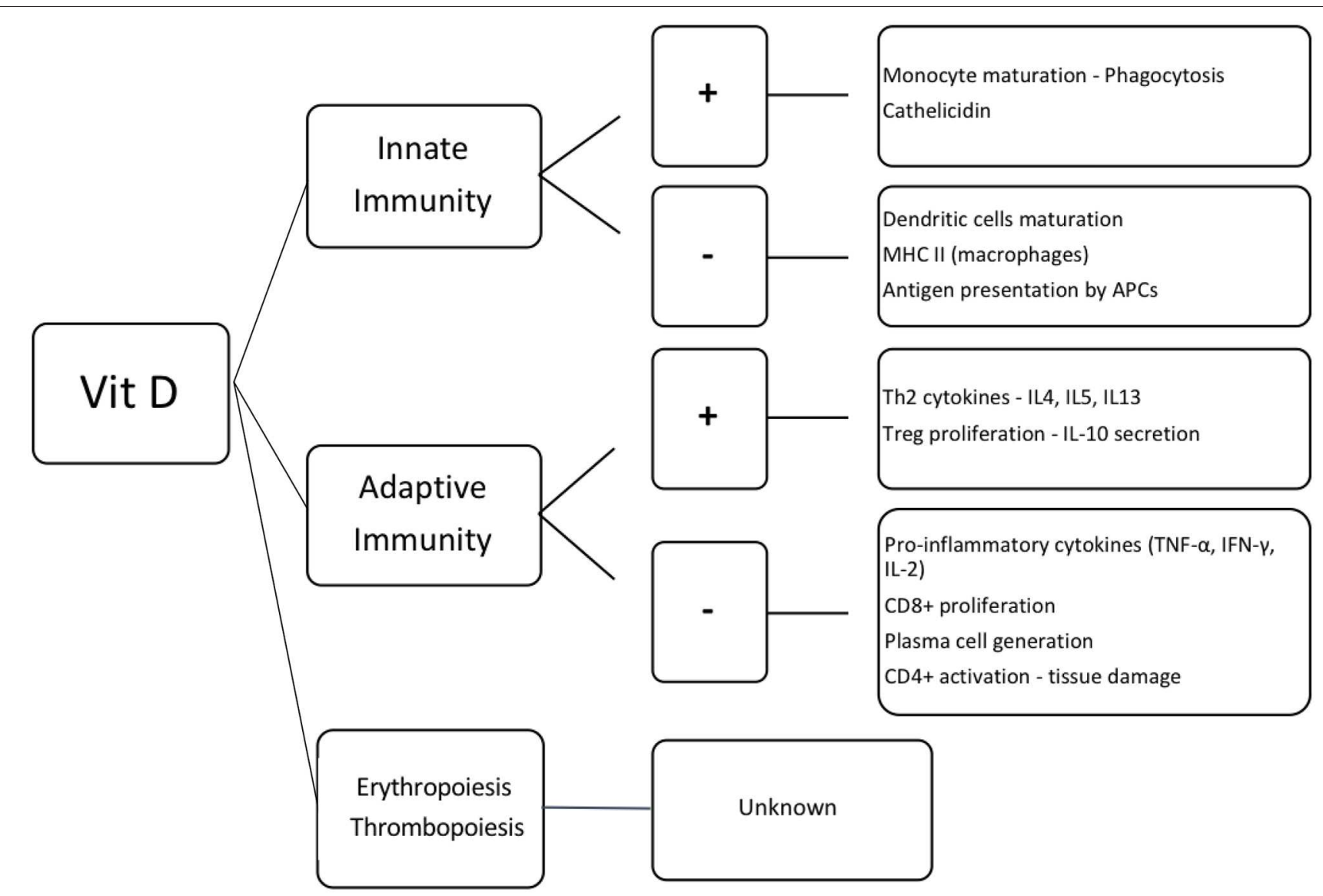

FIGURE 2 | Effect of vitamin D in the hematopoietic cells. Vit D, vitamin D; +, activation; -, inhibition; MHC II, major histocompatibility complex class II; APCs, antigen presenting cells; Th2, T helper lymphocytes 2; IL, interleukin; Treg, regulatory T cells; TNF- $\alpha$, tumor necrosis factor $\alpha$; IFN- $\gamma$, interferon $\gamma ;$ CD8 ${ }^{+}$and CD4 ${ }^{+}$, T lymphocytes $\mathrm{CD}^{+}$and $\mathrm{CD}^{+}$, respectively.

\section{IMPACT OF VITAMIN D IN HSCT}

Vitamin D deficiency can contribute to the imbalance of immune homeostasis, shifting from a tolerogenic to a pro-inflammatory status $(89,113)$. In the allogeneic HSCT, this can have an impact on complications post-transplantation, and potentially on survival outcomes $(9,11,114,115)$.

\section{Immune Reconstitution Post-HSCT}

\section{(Figure 2)}

Early immune recovery is characterized by neutrophil engraftment. At this stage, $1,25(\mathrm{OH})_{2} \mathrm{D}^{3}$ may enhance neutrophil recovery, as shown in a pediatric study where patients with higher levels of $25(\mathrm{OH}) \mathrm{D}^{3}$ had a higher neutrophil count at the time of engraftment (10). Nevertheless, other studies have failed to prove this $(11,82)$. Moreover, two reports suggested the contribution of donors' VDR genotype in the late immune reconstitution of $T$ cells $(116,117)$, but data is still limited to draw any conclusion.

Beyond its immune-modulatory properties, $1,25(\mathrm{OH})_{2} \mathrm{D}^{3}$ stimulates proliferation and differentiation of $\mathrm{CD}_{4} 4^{+}$ hematopoietic stem cells (118-120). It also inhibits secretion of pro-inflammatory cytokines, such as IL-6 and subsequently hepcidin production, resulting in stimulation of erythropoiesis (121-123). However, little is known of its effect on thrombopoiesis (124).

\section{Graft-versus-Host Disease}

GvHD is a major complication following allogeneic HSCT and one of its main causes of death (125). Clinical studies have suggested the link between vitamin D deficiency and GvHD $(9,69,82,84)$. Acute GvHD (aGvHD) pathophysiology is characterized by a strong inflammatory reaction (126), while chronic GvHD (cGvHD) shares features of autoimmunity (127, 128). Vitamin D deficiency causes immune imbalance and cytokine dysregulation, with expansion of autoreactive $\mathrm{T}$ cells, enhancing the response of these immunologically competent cells against host antigens, and blunting vitamin $\mathrm{D}$-mediated immune homeostasis $(113,129)$.

Surprisingly, vitamin A has also been suggested to be involved in GvHD pathogenesis (130), but its potential mechanistic effects of on GvHD are yet to be properly characterized (131).

Three clinical studies have linked $1,25(\mathrm{OH})_{2} \mathrm{D}^{3}$ serostatus and acute GvHD (aGvHD): Urbain et al. demonstrated that patients with moderate to severe aGvHD had lower levels of $25(\mathrm{OH}) \mathrm{D}^{3}$ 
TABLE 1 | Observational studies correlating vitamin D status with outcome post-HSCT*.

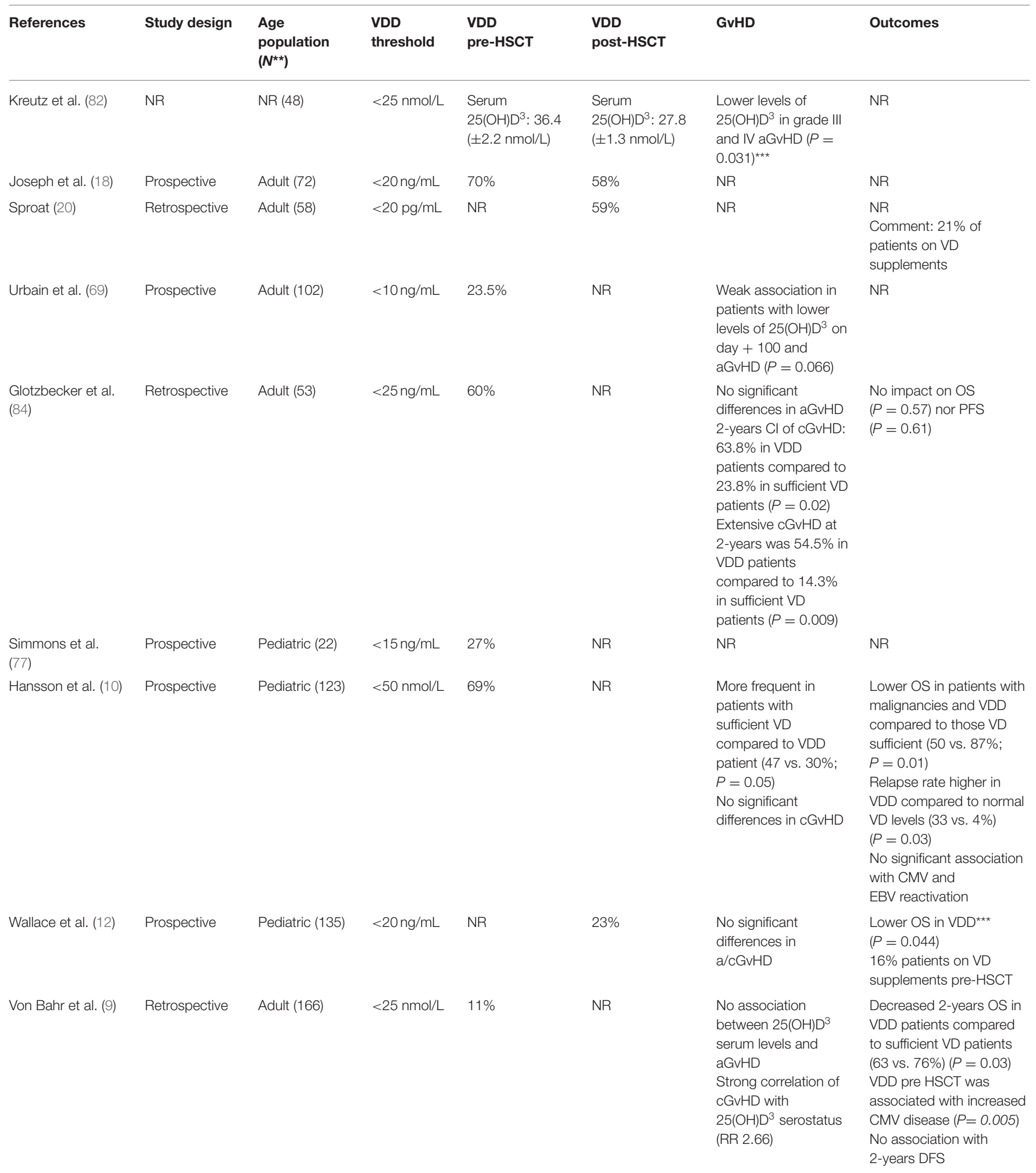


TABLE 1 | Continued

\begin{tabular}{|c|c|c|c|c|c|c|c|}
\hline References & Study design & $\begin{array}{l}\text { Age } \\
\text { population } \\
\left(N^{\star *}\right)\end{array}$ & $\begin{array}{l}\text { VDD } \\
\text { threshold }\end{array}$ & VDD pre-HSCT & $\begin{array}{l}\text { VDD } \\
\text { post-HSCT }\end{array}$ & GvHD & Outcomes \\
\hline $\begin{array}{l}\text { Florenzano et al. } \\
\text { (19) }\end{array}$ & $\begin{array}{l}\text { Retrospective } \\
(36 \% \\
\text { autologous } \\
\text { and } 64 \% \\
\text { allogeneic } \\
\text { HSCT) }\end{array}$ & Adult (46) & $<20 \mathrm{ng} / \mathrm{mL}$ & $17 \%$ & $85 \%$ & NR & $\begin{array}{l}\text { NR } \\
\text { Comment: } 53 \% \text { of } \\
\text { patients on VD } \\
\text { supplements (but not an } \\
\text { interventional study) }\end{array}$ \\
\hline Myers et al. (140) & Retrospective & Pediatric (64) & $<30$ ng/mL & NR & $73 \%$ & NR & NR \\
\hline
\end{tabular}

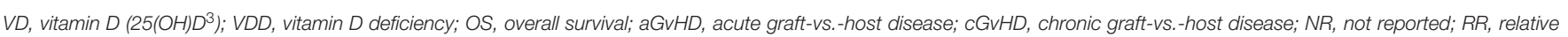
risk; DFS, disease-free survival; PFS, progression-free survival; Cl, cumulative incidence; CMV, cytomegalovirus; EBV, Epstein-Barr virus.

${ }^{\star}$ Studies performed in allogeneic HSCT unless otherwise specified.

${ }^{\star \star} N$, number of participants tested for $25(\mathrm{OH}) D^{3}$.

${ }^{* \star \star}$ Number patients affected $N R$.

after HSCT (69). Kreutz et al. correlated a higher grade of aGvHD with vitamin D deficiency (82). Finally, Ganetsky et al. found that those patients with vitamin D deficiency had an increased risk of grade II-IV skin GvHD (132). Nevertheless, these results could not be reproduced in other studies $(10,69,84,115)$.

Glotzbecker et al. reported that patients with lower levels of $25(\mathrm{OH}) \mathrm{D}^{3}$ prior to HSCT had a higher cumulative incidence of Chronic GvHD (cGvHD) and extensive cGvHD compared to those with higher levels (84). Supporting this, another clinical study showed that cGvHD developed in patients with lower $25(\mathrm{OH}) \mathrm{D}^{3}$ serum levels at transplantation (9). In contrast, other clinical studies failed to find any correlation between vitamin $\mathrm{D}$ serostatus and cGvHD $(10,115,132)$.

Currently there is controversy in the evidence of the impact of vitamin D deficiency within the GvHD pathophysiology. Therefore, further studies with larger sample size to confirm this are warranted.

\section{Resistance To Steroids in GvHD}

More than $50 \%$ of patients treated with steroids for GvHD are resistant to this immunosuppressive treatment (133-135). The cause for this remains unknown but there is strong evidence linking this to a poorer chance of survival in these patients (136).

In the field of asthma, recent studies have linked vitamin D serostatus with steroid resistance: lower levels of serum $25(\mathrm{OH}) \mathrm{D}^{3}$ were associated with poorer steroid response $(72$, 137). Nevertheless, treatment with $1,25(\mathrm{OH})_{2} \mathrm{D}^{3}$ overcame this, resulting in clinical improvement of asthma severity $(66,70,72$, 90). Vitamin D replacement enhanced the expansion of Treg due to the increased secretion of IL-10 by $\mathrm{CD} 4^{+} \mathrm{T}$ cells, previously unresponsive to steroids $(70,72,138)$.

In the steroid-resistant GvHD setting, one preclinical study suggested that synergism between vitamin D supplementation and steroids could abrogate the monocyte-induced release of proinflammatory cytokines and therefore mitigate the tissue damage by GvHD (139).

These findings serve as a rationale for treating or preventing vitamin $\mathrm{D}$ deficiency by upholding normal levels of vitamin $\mathrm{D}$ in order to enhance the immunosuppressive effect. Since vitamin D may overcome the resistance to immunosuppression in GvHD, further research in this field is needed to confirm this hypothesis and potentially to reduce the morbidity and mortality associated to this disease.

\section{Outcomes Post-HSCT (Table 1)}

As previously described, vitamin $\mathrm{D}$ has an immune-modulatory role, and it may protect against infections and blunt tissue damage on the course of $\operatorname{HSCT}(54,91)$. Owing to this, recent studies have tried to elucidate its role in outcomes following allogeneic HSCT, with conflicting results: A prospective study performed in pediatric patients revealed that vitamin D deficiency post-HSCT was associated with a lower overall survival (OS) (114), as seen in other studies evaluating OS at different time points $(9,11,115)$. Nevertheless, further research could not prove the link between vitamin $\mathrm{D}$ serostatus and progression-free survival $(84,115), 2$-years disease-free survival (9), or OS $(84,132,141)$, thus no definitive conclusions can be drawn from them.

\section{VDR as Biomarker in HSCT}

The VDR gene is located in chromosome 12 (142). Specific single nucleotide polymorphism (SNPs) in this gene, such as Fokl FF and ApaI aa reflect upregulation of the VDR activity, whereas ApaI AA downregulates it, impacting on the activity of Th1 and Th2 on the early immune reconstitution following HSCT (116, 143). Furthermore, other SNPs in the VDR and CYP2R1 genes can increase the concentration of $25(\mathrm{OH}) \mathrm{D}^{3}$ in serum following supplementation with vitamin D $(144,145)$.

The association of VDR gene polymorphisms with major clinical outcomes following HSCT has been investigated in different studies with inconclusive results $(116,143,146-150)$. Therefore, further research in this field is warranted with larger study samples, including more recipients of different donor types (unrelated, haploidentical). 


\section{MANAGEMENT OF VITAMIN D DEFICIENCY IN HSCT}

A recent survey performed across European HSCT centers described discrepancies in monitoring and replacement of vitamin D deficiency in HSCT patients: Half of the centers requested vitamin $\mathrm{D}$ prior to transplantation whereas nearly $80 \%$ followed this practice after it. The main reason for this could be that guidelines only recommend measuring vitamin $\mathrm{D}$ in the post-HSCT setting, aiming to prevent bone loss and fractures. Moreover, the cut-off for serum $25(\mathrm{OH}) \mathrm{D}^{3}$ to commence on vitamin $\mathrm{D}$ therapy varied across centers depending on geographical location, ranging from 25 to 100 $\mathrm{nmol} / \mathrm{L}$ (14). Awareness of the immune-regulatory properties of vitamin $\mathrm{D}$ and its potential impact on immune reconstitution post-HSCT and GvHD were acknowledged by a minority of centers (24 and 17\%, respectively), being the main reason to commence on vitamin $\mathrm{D}$ therapy the maintenance of calcium metabolism and bone health (62\%). Since the optimal dose of vitamin D replacement has not been standardized yet in the HSCT population and this differs between pediatric and adult population (ranging from 1,000 IU per day to 600,000 IU per week) (11, 64, 141, 151-155), dosage prescribed by HSCT clinicians varied greatly across centers (14).

In summary, these findings reflect the lack of consensus in this topic within the HSCT community, so recommendations were provided to standardize criteria and harmonize the management of the aforementioned deficiency, encouraging monitoring serum $25(\mathrm{OH}) \mathrm{D}^{3}$ prior and after HSCT, and commence on replacement therapy if clinically indicated. Nevertheless, no conclusions were reached regarding the ideal threshold for vitamin D deficiency due to the lack of robust studies including HSCT patients (14). Different studies have used different cut-offs, which can mislead clinicians when implementing the management of vitamin D deficiency in their day-to-day clinical practice. Therefore, clinical

\section{REFERENCES}

1. Moreno LA, Valtueña J, Pérez-López F, González-Gross M. Health effects related to low vitamin D concentrations: beyond bone metabolism. Ann Nutr Metab. (2011) 59:22-7. doi: 10.1159/0003 32070

2. Lee P, Milliken S, Center JR. Hypocalcaemic cardiac failure post BMT secondary to unrecognized vitamin D deficiency. Bone Marrow Transplant. (2008) 42:363-4. doi: 10.1038/bmt.2008.178

3. Provvedini DM, Tsoukas CD, Deftos LJ, Manolagas SC. 1,25Dihydroxyvitamin D3 receptors in human leukocytes. Science. (1983) 221:1181-3.

4. Rosen Y, Daich J, Soliman I, Brathwaite E, Shoenfeld Y. Vitamin D and autoimmunity. Scand J Rheumatol. (2016) 456:439-47. doi: 10.3109/03009742.2016.1151072

5. Hall AC, Juckett MB. The role of vitamin D in hematologic disease and stem cell transplantation. Nutrients. (2013) 5:2206-21. doi: 10.3390/nu5062206

6. Bikle DD. Vitamin D metabolism, mechanism of action, and clinical applications. Chem Biol. (2014) 21:319-29. doi: 10.1016/j.chembiol.2013.12.016

7. Adorini L, Penna G. Control of autoimmune diseases by the vitamin D endocrine system. Nat Clin Pract Rheumatol. (2008) 4:404-12. doi: $10.1038 /$ ncprheum 0855 outcomes may differ among studies and this can complicate the use of serum $25(\mathrm{OH}) \mathrm{D}^{3}$ as a biomarker in the HSCT landscape. Since this is the only survey performed in the allogeneic HSCT landscape and the recommendations provided are based on upto-date clinical evidence, it seems reasonable to follow them.

\section{CONCLUSIONS}

Vitamin D is a potent regulator of immune responses with impact in HSCT (9-13). Nevertheless, there are no clinical guidelines focusing on vitamin D status and its optimal levels required for prevention of post-transplant complications and enhancement of the immunosuppressive therapy. As a consequence, monitoring vitamin $\mathrm{D}$ can be easily neglected in the management of these complex patients.

The high incidence of vitamin D deficiency in allogeneic HSCT patients, alongside the current controversy (9, 11, 84, 114, $115,132,141)$, emphasizes the need for further studies on the impact of vitamin D deficiency and VDR gene polymorphisms on clinical outcomes to define its role as a biomarker in this setting.

Vitamin D deficiency may be the first potential easily modifiable host factor associated with post-allogeneic HSCT outcomes, thus identifying patients at high risk and optimizing its management to enable prompt therapeutic intervention is encouraged.

\section{AUTHOR CONTRIBUTIONS}

JSo lead the manuscript writing and CA, AM, and JSn contributed to it. All authors accepted the final version of the manuscript.

\section{FUNDING}

Anthony Nolan Research Institute funded this work.
8. Baeke F, Takiishi T, Korf H, Gysemans C, Mathieu C. Vitamin D: modulator of the immune system. Curr Opin Pharmacol. (2010) 10:482-96. doi: 10.1016/j.coph.2010.04.001

9. von Bahr L, Blennow O, Alm J, Björklund A, Malmberg KJ, Mougiakakos $\mathrm{D}$, et al. Increased incidence of CMV disease in patients with vitamin D deficiency before allogeneic stem cell transplantation. Bone Marrow Transplant. (2015) 50:S403-4. doi: 10.1038/bmt.2015.123

10. Hansson ME, Norlin AC, Omazic B, Wikström AC, Bergman P, Winiarski J, et al. Vitamin D levels affect outcome in pediatric hematopoietic stem cell transplantation. Biol Blood Marrow Transplant. (2014) 20:1537-43. doi: 10.1016/j.bbmt.2014.05.030

11. Beebe K, Magee K, McNulty A, Stahlecker J, Salzberg D, Miller H, et al. Vitamin D deficiency and outcomes in pediatric hematopoietic stem cell transplantation. Pediatr Blood Cancer. (2018) 65:1-6. doi: 10.1002/pbc.26817

12. Wallace G, Jodele S, Howell J, Myers KC, Teusink A, Zhao X, et al. Vitamin $\mathrm{D}$ deficiency and survival after hematopoietic stem cell transplantation. Biol Blood Marrow Transpl. (2015) 21:S79-107. doi: 10.1016/j.bbmt.2014.11.130

13. Ros-Soto J, Anthias C, Madrigal A, Snowden JA. Vitamin D: is it important in haematopoietic stem cell transplantation? A review. Bone Marrow Transplant. (2019) 54:810-20. doi: 10.1038/s41409-018-0377-0

14. Ros-Soto J, Snowden JA, Salooja N, Gilleece M, Parker A, Greenfield $\mathrm{DM}$, et al. Current practice in vitamin D management in allogeneic haematopoietic stem cell transplantation: a survey by the Transplant 
Complications Working Party of the EBMT. Biol Blood Marrow Transplant. (2019) 25:2079-85. doi: 10.1016/j.bbmt.2019.06.015

15. van der Meij BS, de Graaf P, Wierdsma NJ, Langius JA, Janssen JJ, van Leeuwen PA, et al. Nutritional support in patients with GVHD of the digestive tract: state of the art. Bone Marrow Transplant. (2013) 48:474-82. doi: 10.1038/bmt.2012.124

16. Greenfield DM, Boland E, Ezaydi Y, Ross RJ, Ahmedzai SH, Snowden $\mathrm{JA}$, et al. Endocrine, metabolic, nutritional and body composition abnormalities are common in advanced intensively-treated (transplanted) multiple myeloma. Bone Marrow Transplant. (2014) 49:907-12. doi: $10.1038 / \mathrm{bmt} .2014 .63$

17. Majhail NS, Rizzo JD, Lee SJ, Aljurf M, Atsuta Y, Bonfim C, et al. Recommended screening and preventive practices for long-term survivors after hematopoietic cell transplantation. Biol Blood Marrow Transpl. (2012) 18:348-71. doi: 10.1016/j.bbmt.2011.12.519

18. Joseph RW, Alousi A, Konda B, Komanduri K, Neumann J, Trevino C, et al. High incidence of vitamin D deficiency in patients undergoing allogeneic stem cell transplantation. Am J Hematol. (2011) 86:954-6. doi: 10.1002/ajh.22143

19. Florenzano P, Ernst D, Lustig N, Rojas P, Ramírez P, Campusano C. Salud ósea en pacientes sometidos a trasplante de precursores hematopoyéticos: un nuevo problema a considerar TT-Vitamin D and parathyroid hormone levels and bone mineral density in patients undergoing hematopoietic cell transplantation. Rev Med Chil. (2016) 144:1119-24. doi: $10.4067 /$ S0034-98872016000900004

20. Sproat L, Bolwell B, Rybicki L, Dean R, Sobecks R, Pohlman B, et al. Vitamin D level after allogeneic hematopoietic stem cell transplant. Biol Blood Marrow Transplant. (2009) 17:1079-83. doi: 10.1016/j.bbmt.2010.12.704

21. Mellanby E. Discussion on the importance of accessory factors (vitamines) in the feeding of infants. Proc R Soc Med. (1920) 13:57-77.

22. Mellanby E. Deficiency diseases, with special reference to rickets. $\mathrm{Br} \mathrm{Med} \mathrm{J.}$ (1924) 1:895-900.

23. Mellanby E. Some common defects in diet and their pathological significance. Br Med J. (1922) 1:790-1.

24. Ross AC, Taylor CL, Yaktine AL, Valle HB Del. Dietary Reference Intakes Calcium and Vitamin D. Washington, DC: The National Academies Press (2010).

25. Valtueña J, González-Gross M, Huybrechts I, Breidenassel C, Ferrari M, Mouratidou T, et al. Factors associated with vitamin D deficiency in European adolescents: the HELENA study. J Nutr Sci Vitaminol (Tokyo). (2013) 59:161-71. doi: 10.3177/jnsv.5

26. Liu PT, Stenger S, Li H, Wenzel L, Tan BH, Krutzik SR, et al. Toll-like receptor triggering of a vitamin $\mathrm{D}$-mediated human antimicrobial response. Science. (2006) 311:1770. doi: 10.1126/science.1123933

27. Green M. Cod liver oil and tuberculosis Malcolm. Br Med J. (2011) 7505:1-6. doi: $10.1136 /$ bmj.d7505

28. Borel P, Caillaud D, Cano NJ. Vitamin D bioavailability: state of the art. Crit Rev Food Sci Nutr. (2013) 55:1193-205. doi: 10.1080/10408398.2012.688897

29. Wolf G. The discovery of vitamin D: the contribution of Adolf Windaus. $J$ Nutr. (2004) 134:1299-302. doi: 10.1093/jn/134.6.1299

30. Holick MF, MacLaughlin JA, Clark MB, Holick SA, Potts JT, Anderson RR, et al. Photosynthesis of previtamin D3 in human skin and the physiologic consequences. Science. (1980) 210:203-5.

31. Rosen CJ. Vitamin D insufficiency. N Engl J Med. (2011) 364:1379-80. doi: 10.1056/NEJMc1101911\#SA4

32. Christakos S, Dhawan P, Verstuyf A, Verlinden L, Carmeliet G. Vitamin D: metabolism, molecular mechanism of action, and pleiotropic effects. Physiol Rev. (2016) 96:365-408. doi: 10.1152/physrev.00014.2015

33. Lange NE, Litonjua A, Hawrylowicz CM, Weiss S. Vitamin D, the immune system and asthma. Expert Rev Clin Immunol. (2009) 5:693-702. doi: $10.1586 /$ eci.09.53

34. Zehnder D, Bland R, Williams MC, McNinch RW, Howie AJ, Stewart PM, et al. Extrarenal expression of 25-hydroxyvitamin D3-1alpha-hydroxylase. J Clin Endocrinol Metab. (2001) 86:888-94. doi: 10.1210/jcem.86.2.7220

35. Institute of Medicine (US) Standing Committee on the Scientific Evaluation of Dietary Reference. Dietary Reference Intakes for Calcium, Magnesium, Phosphorus, Vitamin D, and Fluoride. Washington, DC: National Academy Press (1997). doi: 10.1111/j.1753-4887.1997.tb01621
36. Deeb KK, Trump DL, Johnson CS. Vitamin D signalling pathways in cancer: potential for anticancer therapeutics. Nat Rev Cancer. (2007) 7:684-700. doi: $10.1038 / \mathrm{nrc} 2196$

37. Carlberg C. Current understanding of the function of the nuclear vitamin $\mathrm{D}$ receptor in response to its natural and synthetic ligands. Recent Results Cancer Res. (2003) 164:29-42. doi: 10.1007/b10889383-0002

38. Katayama Y. Vitamin D receptor: a critical regulator of inter-organ communication between skeletal and hematopoietic systems. J Steroid Biochem Mol Biol. (2019) 190:281-3. doi: 10.1016/j.jsbmb.2019.02.001

39. McLean FC, Budy AM. Vitamin A, vitamin D, cartilage, bones, and teeth. In: Harris RS, Wool IG, Loraine JA, editors. Vitamins and Hormones. New York, NY; London, UK: Academy Press (1964). p. 51-2.

40. Lehmann U, Hirche F, Stangl GI, Hinz K, Westphal S. Bioavailability of Vitamin D2 and D3 in healthy volunteers, a randomized placebo-controlled trial. J Clin Endocrinol Metab. (2013) 98:4339-45. doi: 10.1210/jc.2012-4287

41. van Etten E, Mathieu C. Immunoregulation by 1,25-dihydroxyvitamin D3: basic concepts. J Steroid Biochem Mol Biol. (2005) 97:93-101. doi: $10.1016 /$ j.jsbmb.2005.06.002

42. Rolf L, Muris AH, Hupperts R, Damoiseaux J. Vitamin D effects on B cell function in autoimmunity. Ann NY Acad Sci. (2014) 1317:84-91. doi: $10.1111 /$ nyas. 12440

43. Barragan M, Good M, Kolls JK. Regulation of dendritic cell function by vitamin D. Nutrients. (2015) 7:8127-51. doi: 10.3390/nu7095383

44. Bscheider M, Butcher EC. Vitamin D immunoregulation through dendritic cells. Immunology. (2016) 148:227-36. doi: 10.1111/imm.12610

45. Benrashid M, Moyers K, Mohty M, Savani BN. Vitamin D deficiency, autoimmunity, and graft-versus-host-disease risk: Implication for preventive therapy. Exp Hematol. (2012) 40:263-7. doi: 10.1016/j.exphem.2012. 01.006

46. Weeres MA, Robien K, Ahn YO, Neulen ML, Bergerson R, Miller JS, et al. The effects of 1,25-dihydroxyvitamin D3 on in vitro human NK cell development from hematopoietic stem cells. J Immunol. (2014) 193:3456-62. doi: 10.4049/jimmunol.1400698

47. Lemire JM, Adams JS, Sakai R, Jordan SC. 1a,25-Dihydroxyvitamin D3 suppresses proliferation and immunoglobulin production by normal human peripheral blood mononuclear cells. J Clin Invest. (1984) 74:657-61.

48. Armanini D, Andrisani A, Ambrosini G, Donà G, Camozzi V, Bordin L, et al. Interrelationship between vitamin $\mathrm{D}$ insufficiency, calcium homeostasis, hyperaldosteronism, and autoimmunity. J Clin Hypertens. (2016) 18:614-6. doi: $10.1111 /$ jch. 12822

49. Sarkar S, Hewison M, Studzinski GP, Li YC, Kalia V. Role of vitamin D in cytotoxic T lymphocyte immunity to pathogens and cancer. Crit Rev Clin Lab Sci. (2015) 8363:1-14. doi: 10.3109/10408363.2015.1094443

50. Joseph RW, Bayraktar UD, Kim TK, St John LS, Popat U, Khalili J, et al. Vitamin D receptor upregulation in alloreactive human T cells. Hum Immunol. (2012) 73:693-8. doi: 10.1016/j.humimm.2012.04.019

51. Edfeldt K, Liu PT, Chun R, Fabri M, Schenk M, Wheelwright M, et al. T-cell cytokines differentially control human monocyte antimicrobial responses by regulating vitamin D metabolism. Proc Natl Acad Sci USA. (2010) 107:225938. doi: 10.1073/pnas. 1011624108

52. Baeke F, Korf H, Overbergh L, van Etten E, Verstuyf A, Gysemans C, et al. Human $\mathrm{T}$ lymphocytes are direct targets of 1,25-dihydroxyvitamin D3in the immune system. J Steroid Biochem Mol Biol. (2010) 121:221-7. doi: 10.1016/j.jsbmb.2010.03.037

53. Takahashi K, Nakayama Y, Horiuchi H, Ohta T, Komoriya K, Ohmori H, et al. Human neutrophils express messenger RNA of vitamin D receptor and respond to 1 $\alpha, 25$-dihydroxyvitamin D3. Immunopharmacol Immunotoxicol. (2002) 24:335-47. doi: 10.1081/IPH-120014721

54. Muto A, Kizaki M, Yamato K, Kawai Y, Kamata-Matsushita M, Ueno H, et al. 1,25-Dihydroxyvitamin D3 induces differentiation of a retinoic acidresistant acute promyelocytic leukemia cell line (UF-1) associated with expression of p21(WAF1/CIP1) and p27(KIP1). Blood. (1999) 93:2225-33.

55. Rosenblatt J, Bissonnette A, Ahmad R, Wu Z, Vasir B, Stevenson K, et al. Immunomodulatory effects of vitamin D: implications for GVHD. Bone Marrow Transplant. (2010) 45:1463-8. doi: 10.1038/bmt.2009.366

56. Adorini L, Penna G, Casorati M, Davalli AM, Gregori S. Induction of transplantation tolerance by 1,25-dihydroxyvitamin D3. Transplant Proc. (2001) 33:58-9. doi: 10.1016/S0041-1345(00)02262-4 
57. Adorini L, Penna G. Dendritic cell tolerogenicity: a key mechanism in immunomodulation by vitamin D receptor agonists. Hum Immunol. (2009) 70:345-52. doi: 10.1016/j.humimm.2009.01.016

58. Jeng L, Yamshchikov AV, Judd SE, Blumberg HM, Martin GS, Ziegler TR, et al. Alterations in vitamin D status and anti-microbial peptide levels in patients in the intensive care unit with sepsis. J Transl Med. (2009) 7:28. doi: 10.1186/1479-5876-7-28

59. Bruns H, Büttner M, Fabri M, Mougiakakos D, Bittenbring JT, Hoffmann $\mathrm{MH}$, et al. Vitamin D-dependent induction of cathelicidin in human macrophages results in cytotoxicity against high-grade B cell lymphoma. Sci Transl Med. (2015) 7:1-14. doi: 10.1126/scitranslmed.aaa3230

60. Grubczak K, Lipinska D, Eljaszewicz A, Singh P, Radzikowska U, Miklasz $\mathrm{P}$, et al. Vitamin D3 treatment decreases frequencies of CD16-positive and TNF- $\alpha$-secreting monocytes in asthmatic patients. Int Arch Allergy Immunol. (2015) 166:170-6. doi: 10.1159/000380882

61. Ota K, Dambaeva S, Kim MW, Han AR, Fukui A, Gilman-Sachs A, et al. 1,25-Dihydroxy-vitamin D3 regulates NK-cell cytotoxicity, cytokine secretion, and degranulation in women with recurrent pregnancy losses. Eur J Immunol. (2015) 45:3188-99. doi: 10.1002/eji.201545541

62. Cantorna MT, Snyder L, Lin YD, Yang L. Vitamin D and $1,25(\mathrm{OH})_{2} \mathrm{D}$ regulation of T cells. Nutrients. (2015) 7:3011-21. doi: 10.3390/nu7043011

63. Prietl B, Treiber G, Pieber TR, Amrein K. Vitamin D and immune function. Nutrients. (2013) 5:2502-21. doi: 10.3390/nu5072502

64. Caballero-Velázquez T, Montero I, Sánchez-Guijo F, Parody R, Saldaña R, Valcarcel D, et al. Immunomodulatory effect of vitamin D after allogeneic stem cell transplantation: results of a prospective multicenter clinical trial. Clin Cancer Res. (2016) 22:5673-81. doi: 10.1158/1078-0432.CCR-16-0238

65. Rigby WFC, Stacy T, Fanger MW. Inhibition of T lymphocyte mitogenesis by 1,25-Dihydroxyvitamin D3 (Calcitriol). J Clin Invest. (1984) 3:1451-5.

66. Xystrakis E, Kusumakar S, Boswell S, Peek E, Urry Z, Richards DF, et al. Reversing the defective induction of IL-10-secreting regulatory $\mathrm{T}$ cells in glucocorticoid-resistant asthma patients. J Clin Invest. (2006) 116:146-55. doi: 10.1172/JCI21759.146

67. Barrat FJ, Cua DJ, Boonstra A, Richards DF, Crain C, Savelkoul HF, et al. In vitro generation of interleukin 10-producing regulatory $\mathrm{CD} 4(+) \mathrm{T}$ cells is induced by immunosuppressive drugs and inhibited by $\mathrm{T}$ helper type 1 (Th1)- and Th2-inducing cytokines. J Exp Med. (2002) 195:603-16. doi: 10.1084/jem.20011629

68. Yu S, Bruce D, Froicu M, Weaver V, Cantorna MT. Failure of T cell homing, reduced $\mathrm{CD} 4 / \mathrm{CD} 8$ alphaalpha intraepithelial lymphocytes, and inflammation in the gut of vitamin D receptor KO mice. Proc Natl Acad Sci USA. (2008) 105:20834-9. doi: 10.1073/pnas.0808700106

69. Urbain P, Ihorst G, Biesalski H-K, Bertz H. Course of serum 25hydroxyvitamin D3 status and its influencing factors in adults undergoing allogeneic hematopoietic cell transplantation. Ann Hematol. (2012) 91:75966. doi: 10.1038/bmt.2012.158

70. Urry Z, Chambers ES, Xystrakis E, Dimeloe S, Richards DF, Gabryšová L, et al. The role of 1 $\alpha, 25$-dihydroxyvitamin D3 and cytokines in the promotion of distinct Foxp3 ${ }^{+}$and IL-10 ${ }^{+} \mathrm{CD}^{+}{ }^{+}$T cells. Eur J Immunol. (2012) 42:269708. doi: 10.1002/eji.201242370

71. Edinger M, Hoffmann P, Ermann J, Drago K, Fathman CG, Strober S, et al. $\mathrm{CD} 4{ }^{+} \mathrm{CD} 25^{+}$regulatory $\mathrm{T}$ cells preserve graft-versus-tumor activity while inhibiting graft-versus-host disease after bone marrow transplantation. Nat Med. (2003) 9:1144-50. doi: 10.1038/nm915

72. Chambers ES, Nanzer AM, Richards DF, Ryanna K, Freeman AT, Timms $\mathrm{PM}$, et al. Serum 25-dihydroxyvitamin D levels correlate with CD4 ${ }^{+} \mathrm{Foxp}^{+}$ T-cell numbers in moderate/severe asthma. J Allergy Clin Immunol. (2012) 130:542-4. doi: 10.1016/j.jaci.2012.04.022

73. Holick MF. The vitamin D deficiency pandemic and consequences for nonskeletal health: mechanisms of action Michael. Mol Asp Med. (2008) 29:361-8. doi: 10.1016/j.mam.2008.08.008

74. Hyppönen E, Power C. Hypovitaminosis D in British adults at age $45 \mathrm{y}$ : nationwide cohort study of dietary and lifestyle predictors 1-3. Am J Clin Nutr. (2007) 85:860-8. doi: 10.1093/ajcn/85.3.860

75. González-Gross M, Valtueña J, Breidenassel C, Moreno LA, Ferrari M, Kersting M, et al. Vitamin D status among adolescents in Europe: the healthy lifestyle in Europe by nutrition in adolescence study. Br J Nutr. (2012) 107:755-64. doi: 10.1017/S0007114511003527
76. Cashman KD, Dowling KG, Škrabáková Z, Gonzalez-Gross M, Valtueña J, De Henauw S, et al. Vitamin D deficiency in Europe: pandemic? (2016) 103:1033-44. doi: 10.3945/ajcn.115.120873

77. Simmons J, Sheedy C, Lee H, Koh S, Alvarez J, Koyama T, et al. Prevalence of 25-hydroxyvitamin D deficiency in child and adolescent patients undergoing hematopoietic cell transplantation compared to a healthy population. Pediatr Blood Cancer. (2013) 60:2025-30. doi: 10.1002/pbc

78. Wood CL, Cheetham TD. Vitamin D: increasing supplement use among atrisk groups (NICE guideline PH56). Arch Dis Child Educ Pract Ed. (2016) 101:43-5. doi: 10.1136/archdischild-2015-308299

79. Hewison M. An update on vitamin D and human immunity. Clin Endocrinol (Oxf). (2012) 76:315-25. doi: 10.1111/j.1365-2265.2011.04261.x

80. Grenet O, Bobadilla M, Chibout SD, Steiner S. Evidence for the impairment of the vitamin D activation pathway by cyclosporine A. Biochem Pharmacol. (2000) 59:267-72. doi: 10.1016/S0006-2952(99)00321-4

81. Wang TJ, Zhang F, Richards JB, Kestenbaum B, van Meurs JB, Berry D, et al. Common genetic determinants of vitamin D insufficiency: a genome-wide association study. Lancet. (2010) 376:180-8. doi: 10.1016/S0140-6736(10)60588-0

82. Kreutz M, Eissner G, Hahn J, Andreesen R, Drobnik W, Holler E. Variations in 1a,25-dihydroxyvitamin D3 and 25-hydroxyvitamin D3 serum levels during allogeneic bone marrow transplantation bone. Bone Marrow Transplant. (2004) 33:871-3. doi: 10.1038/sj.bmt.1704448

83. Myers KC, Howell JC, Wallace G, Dandoy C, El-Bietar J, Lane A, et al. Poor growth, thyroid dysfunction and vitamin $\mathrm{D}$ deficiency remain prevalent despite reduced intensity chemotherapy for hematopoietic stem cell transplantation in children and young adults. Bone Marrow Transplant. (2016) 51:980-4. doi: 10.1038/bmt.2016.39

84. Glotzbecker B, Ho VT, Aldridge J, Kim HT, Horowitz G, Ritz J, et al. Low levels of 25-hydroxyvitamin D before allogeneic hematopoietic SCT correlate with the development of chronic GVHD. Bone Marrow Transplant. (2013) 48:593-7. doi: 10.1038/bmt.2012.177

85. Prentice A. Vitamin D and health. Sci Advis Comm Nutr. (2016) 7:56-116. doi: 10.1007/s00198-015-3440-3

86. Holick MF. Vitamin D: evolutionary, physiological and health perspectives. Curr Drug Targets. (2011) 12:4-18. doi: 10.2174/138945011793591635

87. Lopes Marques C. The Importance of vitamin D levels in autoimmune disease. Bras J Rheumatol. (2010) 50:67-80. doi: 10.1590/S0482-50042010000100007

88. Muscogiuri G, Altieri B, Annweiler C, Balercia G, Pal HB, Boucher BJ, et al. Vitamin D and chronic diseases: the current state of the art. Arch Toxicol. (2017) 91:97-107. doi: 10.1007/s00204-016-1804-x

89. Vasiliou JE, Lui S, Walker SA, Chohan V, Xystrakis E, Bush A, et al. Vitamin $\mathrm{D}$ deficiency induces Th2 skewing and eosinophilia in neonatal allergic airways disease. Allergy Eur J Allergy Clin Immunol. (2014) 69:1380-9. doi: 10.1111/all.12465

90. Nanzer AM, Chambers ES, Ryanna K, Freeman AT, Colligan G, Richards DF, et al. The effects of calcitriol treatment in glucocorticoid-resistant asthma. J Allergy Clin Immunol. (2014) 133:1755-7.e4. doi: 10.1016/j.jaci.2014. 03.015

91. Yamshchikov AV, Desai NS, Blumberg HM, Ziegler TR, Tangpricha V. Vitamin D for treatment and prevention of infectious diseases: a systemic review of randomized controlled trials. Endocr Pr. (2010) 15:438-49. doi: 10.4158/EP09101.ORR.VITAMIN

92. Rieder FJJ, Gröschel C, Kastner MT, Kosulin K, Laengle J, Zadnikar R, et al. Human cytomegalovirus infection downregulates vitamin-D receptor in mammalian cells. J Steroid Biochem Mol Biol. (2017) 165:356-62. doi: 10.1016/j.jsbmb.2016.08.002

93. Cannell JJ, Vieth R, Umhau JC, Holick MF, Grant WB, Madronich S, et al. Epidemic influenza and vitamin D. Epidemiol Infect. (2006) 134:1129. doi: 10.1017/S0950268806007175

94. Consolini R, Pala S, Legitimo A, Crimaldi G, Ferrari S, Ferrari S. Effects of vitamin D on the growth of normal and malignant B-cell progenitors. Clin Exp Immunol. (2001) 126:214-9. doi: 10.1046/j.1365-2249.2001.01671.x

95. Kumagai T, O’Kelly J, Said JW, Koeffler HP. Vitamin D2 analog 19-nor-1,25-dihydroxyvitamin D2: antitumor activity against leukemia, myeloma, and colon cancer cells. J Natl Cancer Inst. (2003) 95:896-905. doi: 10.1093/jnci/95.12.896 
96. Hughes PJ, Marcinkowska E, Gocek E, Studzinski GP, Brown G. Vitamin D3-driven signals for myeloid cell differentiationimplications for differentiation therapy. Leuk Res. (2010) 34:553-65. doi: 10.1016/j.leukres.2009.09.010

97. Shanafelt TD, Drake MT, Maurer MJ, Allmer C, Rabe KG, Slager SL, et al. Vitamin D insufficiency and prognosis in chronic lymphocytic leukemia. Blood. (2016) 117:1492-9. doi: 10.1182/blood-2010-07-295683

98. Gedikoglu G, Altinoz MA. Differentiation-inducing liposoluble vitamin deficiency may explain frequent secondary solid tumors after hematopoietic stem cell transplantation: minireview. Neoplasma. (2008) 55:1-9.

99. Newton-Bishop JA, Beswick S, Randerson-Moor J, Chang YM, Affleck P, Elliott F, et al. Serum 25-hydroxyvitamin D 3 levels are associated with Breslow thickness at presentation and survival from melanoma. J Clin Oncol. (2009) 27:5439-44. doi: 10.1200/JCO.2009.22.1135

100. Egan KM, Sosman JA, Blot WJ. Sunlight and reduced risk of cancer: Is the real story vitamin D? J Natl Cancer Inst. (2005) 97:161-3. doi: 10.1093/jnci/dji047

101. Goodwin PJ, Ennis M, Pritchard KI, Koo J, Hood N. Prognostic effects of 25-hydroxyvitamin D levels in early breast cancer. J Clin Oncol. (2009) 27:3757-63. doi: 10.1200/JCO.2008.20.0725

102. Millen AE, Bodnar LM. Vitamin D assessment in population-based studies : a review of the issues. Am J Clin Nut. (2008) 87:1102S-5S. doi: 10.1093/ajen/87.4.1102S

103. Zhou W, Heist RS, Liu G, Asomaning K, Neuberg DS, Hollis BW, et al. Circulating 25-hydroxyvitamin D levels predict survival in earlystage non-small-cell lung cancer patients. J Clin Oncol. (2007) 25:479-85. doi: $10.1200 /$ JCO.2006.07.5358

104. Courbebaisse M, Souberbielle JC, Thervet E. Potential nonclassical effects of vitamin D in transplant recipients. Transplantation. (2010) 89:131-7. doi: 10.1097/TP.0b013e3181c6910f

105. Radujkovic A, Schnitzler P, Ho AD, Dreger P, Luft T. Low serum vitamin D levels are associated with shorter survival after first-line azacitidine treatment in patients with myelodysplastic syndrome and secondary oligoblastic acute myeloid leukemia. Clin Nutr. (2017) 36:542-51. doi: 10.1016/j.clnu.2016.01.021

106. Bittenbring T, Neumann F, Altmann B, Achenbach M, Ziepert M. Vitamin $\mathrm{D}$ deficiency impairs rituximab-mediated cellular cytotoxicity and outcome of patients with diffuse large B-cell lymphoma treated with but not without rituximab. J Clin Oncol. (2017) 32:3242-8. doi: 10.1200/JCO.2013.53.4537

107. Lim U, Freedman DM, Hollis BW, Horst RL, Purdue MP, Chatterjee $\mathrm{N}$, et al. A prospective investigation of serum 25-hydroxyvitamin $\mathrm{D}$ and risk of lymphoid cancers. Int J Cancer. (2009) 124:979-86. doi: 10.1371/journal.pone.0178059

108. Purdue MP, Freedman DM, Gapstur SM, Helzlsouer KJ, Laden F, Lim U, et al. Circulating 25-hydroxyvitamin D and risk of non-Hodgkin lymphoma: cohort consortium vitamin $\mathrm{D}$ pooling project of rarer cancers. Am J Epidemiol. (2010) 172:58-69. doi: 10.1093/aje/kwq117

109. Radujkovic A, Kordelas L, Krzykalla J, Beelen DW, Benner A, Lehners N, et al. Pretransplant vitamin D deficiency is associated with higher relapse rates in patients allografted for myeloid malignancies. J Clin Oncol. (2019) 35:3143-52. doi: 10.1200/JCO.2017.73.0085

110. Stein EM, Cohen A, Freeby M, Rogers H, Kokolus S, Scott V, et al. Severe vitamin D deficiency among heart and liver transplant recipients. Clin Transpl. (2009) 23:861-5. doi: 10.1111/j.1399-0012.2009.00989.x

111. Verleden SE, Vos R, Geenens R, Ruttens D, Vaneylen A, Dupont LJ, et al. Vitamin D deficiency in lung transplant patients: Is it important? Transplantation. (2012) 93:224-9. doi: 10.1097/TP.0b013e31823d98bc

112. Sarno G, Nappi R, Altieri B, Tirabassi G, Muscogiuri E, Salvio G, et al. Current evidence on vitamin D deficiency and kidney transplant: what's new? Rev Endocr Metab Disord. (2017) 18:323-34. doi: 10.1007/s11154-017-9418-z

113. Arain A, Matthiesen C. Vitamin D deficiency and graft-versus-host disease in hematopoietic stem cell transplant population. Hematol Oncol Stem Cell Ther. (2019) 12:133-9. doi: 10.1016/j.hemonc.2018.08.001

114. Wallace G, Jodele S, Howell J, Myers KC, Teusink A, Zhao X, et al. Vitamin D deficiency and survival in children after hematopoietic stem cell transplant. Biol Blood Marrow Transplant. (2015) 21:1627-31. doi: 10.1016/j.bbmt.2015.06.009
115. Perera T, Ming Lim AB, Mason K, Szer J, Ritchie DS. The relationship between pre-transplant 25-hydroxy-vitamin $\mathrm{d}$ levels, survival and graft-versus-host disease, in allogeneic haematopoietic stem cell transplantation. Biol Blood Marrow Transplant. (2015) 21:S303. doi: 10.1016/j.bbmt.2014.11.482

116. Bogunia-Kubik K, Middleton P, Norden J, Dickinson A, Lange A. Association of vitamin D receptor polymorphisms with the outcome of allogeneic haematopoietic stem cell transplantation. Int J Immunogenet. (2008) 35:20713. doi: 10.1111/j.1744-313X.2008.00758.x

117. Medrano M, Carrillo-Cruz E, Montero I, Perez-Simon JA. Vitamin D: Effect on haematopoiesis and immune system and clinical applications. Int $\mathrm{J} \mathrm{Mol}$ Sci. (2018) 19:1-25. doi: 10.3390/ijms19092663

118. Cortes M, Chen MJ, Stachura DL, Liu SY, Kwan W, Wright F, et al. Developmental vitamin D availability impacts hematopoietic stem cell production. Cell Rep. (2016) 17:458-68. doi: 10.1016/j.celrep.2016.09.012

119. Grande A, Montanari M, Tagliafico E, Manfredini R, Zanocco Marani T, Siena M, et al. Physiological levels of 1alpha, 25 dihydroxyvitamin D3 induce the monocytic commitment of $\mathrm{CD} 34^{+}$hematopoietic progenitors. J Leukoc Biol. (2002) 71:641-51.

120. Eldjerou LK, Cogle CR, Rosenau EH, Lu X, Bennett CA, Sugrue MW, et al. Vitamin D effect on umbilical cord blood characteristics: a comparison between African Americans and Caucasians. Transfusion. (2015) 55:176671. doi: $10.1111 / \operatorname{trf} .13124$

121. Santoro D, Caccamo D, Lucisano S, Buemi M, Sebekova K, Teta D, et al. Interplay of vitamin $\mathrm{D}$, erythropoiesis, and the renin-angiotensin system. Biomed Res Int. (2015) 2015:145828. doi: 10.1155/2015/145828

122. Fattizzo B, Zaninoni A, Giannotta JA, Binda F, Cortelezzi A, Barcellini W. Reduced $25-\mathrm{OH}$ vitamin $\mathrm{D}$ in patients with autoimmune cytopenias, clinical correlations and literature review. Autoimmun Rev. (2016) 15:770-5. doi: 10.1016/j.autrev.2016.03.015

123. Smith EM, Tangpricha V. Vitamin D and anemia: insights into an emerging association. Curr Opin Endocrinol Diabetes Obes. (2015) 22:432-8. doi: 10. 1097/MED.0000000000000199

124. Bockow B, Kaplan TB. Refractory immune thrombocytopenia successfully treated with high-dose vitamin D supplementation and hydroxychloroquine: two case reports. J Med Case Rep. (2013) 7:1. doi: 10.1186/1752-1947-7-91

125. Tyndall A, Dazzi F. Chronic GVHD as an autoimmune disease. Best Pract Res Clin Haematol. (2008) 21:281-9. doi: 10.1016/j.beha.2008.03.003

126. Zeiser R, Socié G, Blazar BR. Pathogenesis of acute graft-versus-host disease: from intestinal microbiota alterations to donor $\mathrm{T}$ cell activation. $\mathrm{Br} \mathrm{J}$ Haematol. (2016) 175:191-207. doi: 10.1111/bjh.14295

127. Holtan SG, Pasquini M, Weisdorf DJ. Acute graft-versushost disease: a bench-to-bedside update. (2017) 124:363-74. doi: 10.1182/blood-2014-01-514786

128. Cooke KR, Luznik L, Sarantopoulos S, Hakim FT, Jagasia M, Fowler DH, et al. The biology of chronic graft-versus-host disease : a task force report from the national institutes of health consensus development project on criteria for clinical trials in chronic graft-versus-host disease. Biol Blood Marrow Transplant. (2017) 23:211-34. doi: 10.1016/j.bbmt.2016.09.023

129. Antico A, Tampoia M, Tozzoli R, Bizzaro N. Can supplementation with vitamin $\mathrm{D}$ reduce the risk or modify the course of autoimmune diseases? A systematic review of the literature. Autoimmun Rev. (2012) 12:127-36. doi: 10.1016/j.autrev.2012.07.007

130. Chen X, Mayne CG. The role of micronutrients in graft-vs.-host disease: immunomodulatory effects of vitamins A and D. Front Immunol. (2018) 9:2853. doi: 10.3389/fimmu.2018.02853

131. Ghimire S, Weber D, Mavin E, Wang XN, Dickinson AM, Holler E. Pathophysiology of GvHD and other HSCT-related major complications. Front Immunol. (2017) 8:79. doi: 10.3389/fimmu.2017.00079

132. Ganetsky A, Richman LP, Frey N V., Vonderheide RH, Porter DL, Reshef R. Vitamin D deficiency predicts acute cutaneous graft-versushost disease in reduced-intensity allogeneic hematopoietic stem cell transplantation. Biol Blood Marrow Transplant. (2014) 20:S267-8. doi: 10.1016/j.bbmt.2013.12.451

133. Dignan FL, Clark A, Amrolia P, Cornish J, Jackson G, Mahendra P, et al. Diagnosis and management of acute graft-versus-host disease. Br J Haematol. (2012) 158:30-45. doi: 10.1111/j.1365-2141.2012.09129.x 
134. Dignan FL, Amrolia P, Clark A, Cornish J, Jackson G, Mahendra P, et al. Diagnosis and management of chronic graft-versus-host disease. $\mathrm{Br} J$ Haematol. (2012) 158:46-61. doi: 10.1111/j.1365-2141.2012.09128.x

135. Dignan FL, Scarisbrick JJ, Cornish J, Clark A, Amrolia P, Jackson $\mathrm{G}$, et al. Organ-specific management and supportive care in chronic graft-versus-host disease. $\mathrm{Br}$ J Haematol. (2012) 158:62-78. doi: 10.1111/j.1365-2141.2012.09131.x

136. Garnett C, Apperley JF, Pavlu J. Treatment and management of graft-versushost disease: improving response and survival. Ther Adv Hematol. (2013) 4:366-78. doi: 10.1177/2040620713489842

137. Ramesh R, Kozhaya L, McKevitt K, Djuretic IM, Carlson TJ, Quintero MA, et al. Pro-inflammatory human Th17 cells selectively express P-glycoprotein and are refractory to glucocorticoids. J Exp Med. (2014) 211:89-104. doi: 10.1084/jem.20130301

138. Zhang Y, Leung DY, Goleva E. Anti-inflammatory and corticosteroidenhancing actions of vitamin $\mathrm{D}$ in monocytes of patients with steroidresistant and those with steroid-sensitive asthma. J Allergy Clin Immunol. (2014) 133:1744-52.e1. doi: 10.1016/j.jaci.2013.12.004

139. Reinhardt-Heller K, Hirschberg I, Lang P, Vogl T, Handgretinger R, Bethge WA, et al. Increase of intermediate monocytes in graft-versus-host disease: correlation with MDR1 + Th17. Biol Blood Marrow Transplant. (2017) 23:2057-64. doi: 10.1016/j.bbmt.2017.08.008

140. Myers KC, Howell JC, Wallace G, El-Bietar J, Lane A, Davies SM, et al. Poor growth, thyroid dysfunction and vitamin $\mathrm{D}$ deficiency remain prevalent despite reduced intensity chemotherapy for hematopoietic stem cell transplantation in children and young adults. Bone Marrow Transplant. (2015) 33:395-401. doi: 10.1038/nbt.3121

141. Campos DJ, Biagini GL, Funke VA, Bonfim CM, Boguszewski CL, Borba VZ. Vitamin D deficiency in children and adolescents submitted to hematopoietic stem cell transplantation. Rev Bras Hematol Hemoter. (2014) 36:126-31. doi: 10.5581/1516-8484.20140029

142. Taymans SE, Pack S, Pak E, Orban Z, Barsony J, Zhuang Z, et al. The human vitamin $\mathrm{D}$ receptor gene (VDR) is localized to region $12 \mathrm{cen}$ q12 by fluorescent in situ hybridization and radiation hybrid mapping: genetic and physical VDR map. J Bone Miner Res. (1999) 14:1163-6. doi: 10.1359/jbmr.1999.14.7.1163

143. Middleton PG, Cullup H, Dickinson AM, Norden J, Jackson GH, Taylor $\mathrm{PR}$, et al. Vitamin D receptor gene polymorphism associates with graft-versus-host disease and survival in HLA-matched sibling allogeneic bone marrow transplantation. Bone Marrow Transpl. (2002) 30:223-8. doi: 10.1038/sj.bmt.1703629

144. Barry EL, Rees JR, Peacock JL, Mott LA, Amos CI, Bostick RM, et al. Genetic Variants in CYP2R1, CYP24A1, and VDR modify the efficacy of vitamin D3 supplementation for increasing serum 25-hydroxyvitamin D levels in a. $J$ Clin Endocrinol Metab. (2014) 99:E2133-7. doi: 10.1210/jc.2014-1389

145. Nissen J, Rasmussen LB, Ravn-Haren G, Andersen EW, Hansen B, Andersen $\mathrm{R}$, et al. Common variants in CYP2R1 and GC genes predict vitamin D concentrations in healthy Danish children. PLoS ONE. (2014) 9:e0089907. doi: 10.1371/journal.pone.0089907

146. Cho HJ, Shin DY, Kim JH, Bae JY, Lee KH, See CJ, et al. Impact of vitamin D receptor gene polymorphisms on clinical outcomes of HLA-matched sibling hematopoietic stem cell transplantation. Clin Transpl. (2011) 26:476-83. doi: 10.1111/j.1399-0012.2011.01523.x
147. Rocha V, Porcher R, Fernandes JF, Filion A, Bittencourt H, Silva $\mathrm{W}$, et al. Association of drug metabolism gene polymorphisms with toxicities, graft-versus-host disease and survival after HLA-identical sibling hematopoietic stem cell transplantation for patients with leukemia. Leukemia. (2009) 23:545-56. doi: 10.1038/leu.2008.323

148. Carrillo-Cruz E, García-Lozano JR, Márquez-Malaver FJ, Sánchez-Guijo FM, Montero Cuadrado I, Ferra I Coll C, et al. Vitamin D modifies the incidence of graft-versus-host disease after allogeneic stem cell transplantation depending on the vitamin D receptor (VDR) polymorphisms. Clin Cancer Res. (2019) 25:4616-23. doi: 10.1158/1078-0432.ccr18-3875

149. Kamel AM, El-Fishawi S, Rasekh EO, Radwan ER, Zeidan A, El-Said A, et al. Variability of contribution of vitamin D receptor gene polymorphisms to outcome of HLA-matched sibling allogeneic bone marrow transplantation. Leuk Lymphoma. (2018) 59:2963-72. doi: 10.1080/10428194.2018.14 59608

150. Dickinson AM, Pearce KF, Norden J, O’Brien SG, Holler E, Bickeböller H, et al. Impact of genomic risk factors on outcome after hematopoietic stem cell transplantation for patients with chronic myeloid leukemia. Haematologica. (2010) 95:922-7. doi: 10.3324/haematol.2009.016220

151. Wallace G, Jodele S, Myers KC, Dandoy CE, El-Bietar J, Nelson A, et al. Vitamin D deficiency in pediatric hematopoietic stem cell transplantation patients despite both standard and aggressive supplementation. Biol Blood Marrow Transplant. (2016) 22:1271-4. doi: 10.1016/j.bbmt.2016. 03.026

152. Wallace G, Jodele S, Myers KC, Dandoy CE, El-Bietar J, Nelson A, et al. Single ultra-high-dose cholecalciferol to prevent vitamin D deficiency in pediatric hematopoietic stem cell transplantation. Biol Blood Marrow Transplant. (2018) 24:1856-60. doi: 10.1016/j.bbmt.2018.05.019

153. Duncan CN, Vrooman L, Apfelbaum EM, Whitley K, Bechard L, Lehmann LE. 25-hydroxy vitamin $\mathrm{D}$ deficiency following pediatric hematopoietic stem cell transplant. Biol Blood Marrow Transplant. (2011) 17:749-53. doi: 10.1016/j.bbmt.2010.10.009

154. Robien K, Strayer LG, Majhail N, Lazovich D, Baker KS, Smith AR, et al. Vitamin D status among long-term survivors of hematopoietic cell transplantation. Bone Marrow Transpl. (2012) 46:1472-9. doi: 10.1038/bmt.2010.326

155. Silva F, Pérez-Simón JA, Caballero-Velazquez T, Sánchez-Guijo FM, Villanueva-Gomez F, Vazquez L, et al. Effect of vitamin D treatment in chronic GVHD. Bone Marrow Transplant. (2011) 46:1395-7. doi: $10.1038 / \mathrm{bmt} .2010 .317$

Conflict of Interest: The authors declare that the research was conducted in the absence of any commercial or financial relationships that could be construed as a potential conflict of interest.

Copyright (c) 2020 Soto, Anthias, Madrigal and Snowden. This is an open-access article distributed under the terms of the Creative Commons Attribution License (CC $B Y)$. The use, distribution or reproduction in other forums is permitted, provided the original author(s) and the copyright owner(s) are credited and that the original publication in this journal is cited, in accordance with accepted academic practice. No use, distribution or reproduction is permitted which does not comply with these terms. 